\title{
Triassic Succession of Zelovo Area (Svilaja Mt. - Karst Dinarides, Croatia): A Sedimentary Record from the Epeiric to Isolated Carbonate Platform Transition
}

Damir Bucković ${ }^{\star}$ and Ana Štampar

Department of Geology, Faculty of Science, University of Zagreb, Croatia

\begin{abstract}
The Zelovo area on the foothills of Svilaja Mt. is a well-known area of the thick succession of the Triassic strata. It is composed of Lower Triassic mixed carbonate and siliciclastic beds that were deposited within the epeiric platform depositional realm situated in an equatorial area along the northern Gondwana shelf. The overlying Anisian and Ladinian carbonate beds with pelagic and sporadic more intense pyroclastic characteristics belong to another paleogeographic entity known as the Adria plate, i.e. huge depositional area of the isolated carbonate Southern Tethyan Mega platform. This Lower and Middle Triassic epeiric platform-isolated platform sequence was emerged during Late Ladinian and then submerged again due to Norian transgression, marking renewed carbonate deposition within the isolated carbonate platform realm up to the end of Cretaceous.
\end{abstract}

\section{Introduction}

The term "carbonate platform" can be generally applied to any shallow marine environment where there is an accumulation of carbonate sediment. If the platform is attached to a continental landmass it is called a carbonate shelf, a region of sedimentation that is analogous to shelf environments for terrigenous clastic deposition. Therefore, carbonate shelf environment is very simmilar to epeiric platform environment. Epeiric platforms developed during periods of high global sea level when shallow shelf seas covered large parts of the continents. This allows significant progradation of the carbonate platform margins over hundreds of kilometres, unlike the isolated carbonate platforms that are limited in their progradation by the bordering deep ocean floor [1]. Thus, the isolated carbonate platforms represent shallow-water areas that are completely surrounded by deep water and therefore do not receive, apart from wind-blown dust, any terrigenous clastic supply. The main focus of this paper is a basical description and sedimentological interpretation of one depositional environment from Zelovo area, Svilaja Mt., Karst Dinarides, Croatia, comprising epeiric platform and isolated platform depositional characteristics. Our intention is to display how it can serve as a one single indicator of the large-scale regional paleogeographic events in southern Tethyan realm during Triassic.

\section{Samples and Methods}

For the purpose of this paper one Triassic succession from Zelovo area situated north from town of Split (Svilaja Mt, Karst Dinarides - Croatia) were studied in detail (Figure 1). The methods of field study were common; beds and rock samples were first analysed in their natural state in the field and then 12 oriented samples were collected using a rock pick. From the most significant Middle Triassic samples with algae thin sections were prepared. One thin section was produced when a thin sliver of rock was cut from the rock sample with a diamond saw and grounded optically flat. It was then mounted on a glass slide and then grounded smooth using progressively finer abrasive grit until the sample is only $30 \mu \mathrm{m}$ thick. Then the sample, now as a thin section, was ready for viewing and imaging under the microscope. Therefore, based on these field and laboratory observation under the microscope, various facies within stratigraphic units in vertical succession were identified (Figure 2).

\section{Geological Setting}

According to [2] the Upper Permian shallow marine carbonates of the Karst Dinarides are gradually replaced with thick succession consisting of Lower Triassic shelf siliciclastics and carbonates indicating depositional processes on wide Gondwana passive continental margin, which are, depending on the predominant influence, dominated by either shelf siliciclastic or carbonate deposition. Therefore, the Lower Triassic deposits of Karst Dinarides usually can be divided into two lithostratigraphic units: (1) The lower unit is composed of reddish and violet micaceous clastics, and (2) the Upper unit that consists of grayish to brownish limestones and marls.

The Middle Triassic of the Karst Dinaridic area is characterised by thick sequence of shallow/deeper-water limestones with numerous occurrences of volcanic and volcaniclastic rocks, predominantly in the Ladinian. These widespread Anisian/Ladinian carbonate platform strata could be attributed to a phase when Gondwana shelf experienced the rift tectonics that initiated its desintegration and when the volcanic and volcaniclastic rocks originated [2].

The Middle/Upper Triassic boundary within the Karst Dinaridic strata is mostly characterised by a relatively long (Carnian) emersion phase, including common bauxite occurrences. Therefore, this emersion event was reflected in the Karst Dinarides by the terrestrial deposits underlying the Norian-Rhaetian Hauptdolomite formation. However, in some places, the Middle/Upper Triassic transition period as well as the whole Carnian stage is practically continuous within shallow-marine environments (e.g. in W Slovenia, vicinity of Karlovac in Central Croatia, or W and Central Bosnia and Herzegovina, or N and S Montenegro) [1].

"Corresponding Author: Dr. Damir Bucković , Department of Geology, Faculty of Science, University of Zagreb, Croatia; E-mail: buckovic@geol.pmf.hr

Citation: Bucković D, Štampar A (2016) Triassic Succession of Zelovo Area (Svilaja Mt. - Karst Dinarides, Croatia): A Sedimentary Record from the Epeiric to Isolated Carbonate Platform Transition. Int J Earth Envrion Sci 1: 109. doi: http:// dx.doi.org/10.15344/ijees/2016/109

Copyright: (c) 2016 Bucković et al. This is an open-access article distributed under the terms of the Creative Commons Attribution License, which permits unrestricted use, distribution, and reproduction in any medium, provided the original author and source are credited. 
Citation: Bucković D, Štampar A (2016) Triassic Succession of Zelovo Area (Svilaja Mt. - Karst Dinarides, Croatia): A Sedimentary Record from the Epeiric to Isolated Carbonate Platform Transition. Int J Earth Envrion Sci 1: 109. doi: http://dx.doi.org/10.15344/ijees/2016/109

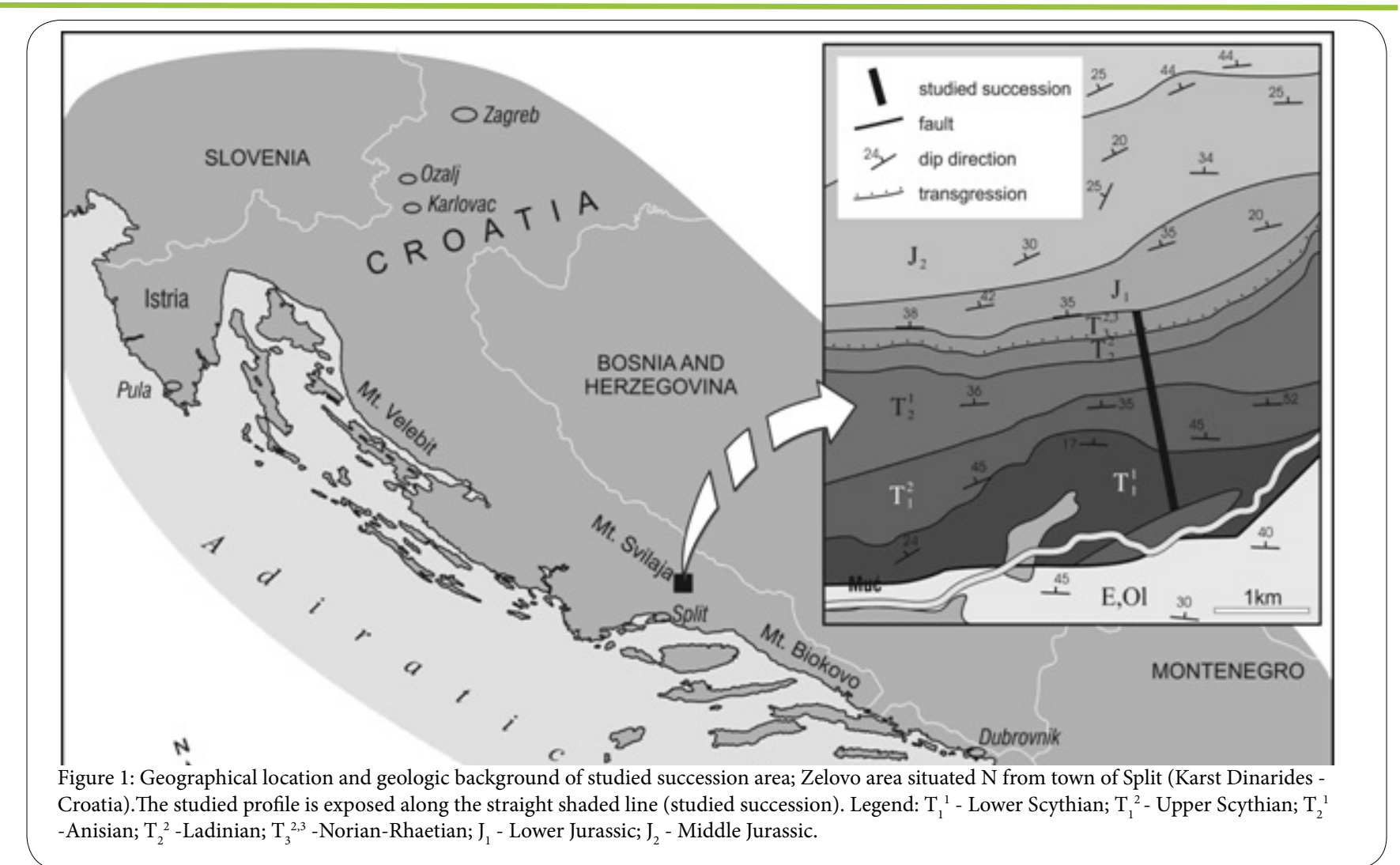

After the Carnian emersion phase, the Norian-Rhaetian in the entire Karst Dinaridic area is characterised by a widespread marine transgression that initiated the deposition of a thick series of peritidal shelf limestones and early diagenetic dolomite (Hauptdolomite), marking a new stage in the evolution of the carbonate platform deposition.

\section{Description of the Sedimentary Record}

The Lower Triassic succession at the Zelovo area are trust over the underlying Eocene carbonates succession and therefore tectonically reduced in their lower part. Here in Croatia as well as in the Southern Alps, two informal lithostratigraphic units can be distinguished within the Lower Triassic succession. The older, tectonically reduced unit is coeval with the Early Scythian stage, which is today not included in the official time scales but can be commonly found in older and current Croatian literature [e.g. 2]. It is composed of thin-bedded, reddish and violet, micaceous siltstones-sandstones, alternating with thicker-bedded, mixed siliciclastic-carbonate intervals composed of oolites and sandstones (analogue to the Seiser beds of the Southern Alps) (Figure 3). These sedimentary facies types are characterized by abundance of various textures, such as sharp lower bedding surfaces, ripple cross-, hummocky cross-and horizontal planar lamination, etc. Increasing occurrence of marly limestones and marls versus siltstonessandstones, oolites and sandstones, followed then by increased occurrence of pure micritic limestones versus marly limestones and marls, is a very prominent characteristic of the overlying Upper Scythian unit (analogue to the Campilian beds of the Southern Alps) (Fig. 3). Well preserved gutter casts, numerous escape burrows and crawling trace fossils, undulatory lamination and hummocky crossstratification are common texture characteristics within the marls and marly limestones of this unit. Contrary to the underlying unit, this unit in its lower part, composed of marls and marly limestones is very rich in various molluscs, such as small gastropods, bivalves and ammonites (Dinarites sp., Tirolites sp.). The thickness of entire Lower Triassic succession in Zelovo area amounts to ca. $330 \mathrm{~m} \mathrm{[2].}$

The boundary between the Scythian and the Anisian is marked by so-called the "Otarnik unit". It is represented by a $13 \mathrm{~m}$ thick interval of carbonate breccias (Figure 4) that pass laterally and vertically into the Anisian carbonates. Textural characteristics of these breccias generally correspond to breccia boundary horizon described a little further in this chapter.

In their thickness of $135 \mathrm{~m}$, Anisian and Ladinian carbonates are characterized by more or less clear traces of volcanism; limestone and dolomite beds are interrupted by numerous $\mathrm{cm}$-to- $\mathrm{dm}$ thick tuff intercalations, a few $\mathrm{mm}$ thick chert intercalations (Figure 5), and frequent pervasive silicification.

The limestone beds include bioclastic wackestones with sporadical abundance of calcitized and/or recrystallized radiolarians, sponge spicules, ostracodes and crinoid ossicles. Particles of undeterminable corals, mollusks, and brahiopods are rarely present. Within the Ladinain succession a $20 \mathrm{~m}$ thick interval of silicified dolomites and limestones that alternate with green, crystaline and vitric tuffs can be observed. These beds are known as "pietra verde" [3] (Figure 6).

The "pietra verde" interval is covered by an $80 \mathrm{~m}$ thick interval of Ladinian bioclastic wackestones-floatstones and dolomites in alteration. The wackestones-floatstones, sporadically also intercalated with chert, frequently contain recrystallized Diplopora annulata Schafhäutl fragments, oncoids, crinoidal detritus and stromatolitic intraclasts. Silicification of limestone beds is quite rare. These carbonates represent the termination of the Ladinian at the Zelovo 
Citation: Bucković D, Štampar A (2016) Triassic Succession of Zelovo Area (Svilaja Mt. - Karst Dinarides, Croatia): A Sedimentary Record from the Epeiric to Isolated Carbonate Platform Transition. Int J Earth Envrion Sci 1: 109. doi: http://dx.doi.org/10.15344/ijees/2016/109

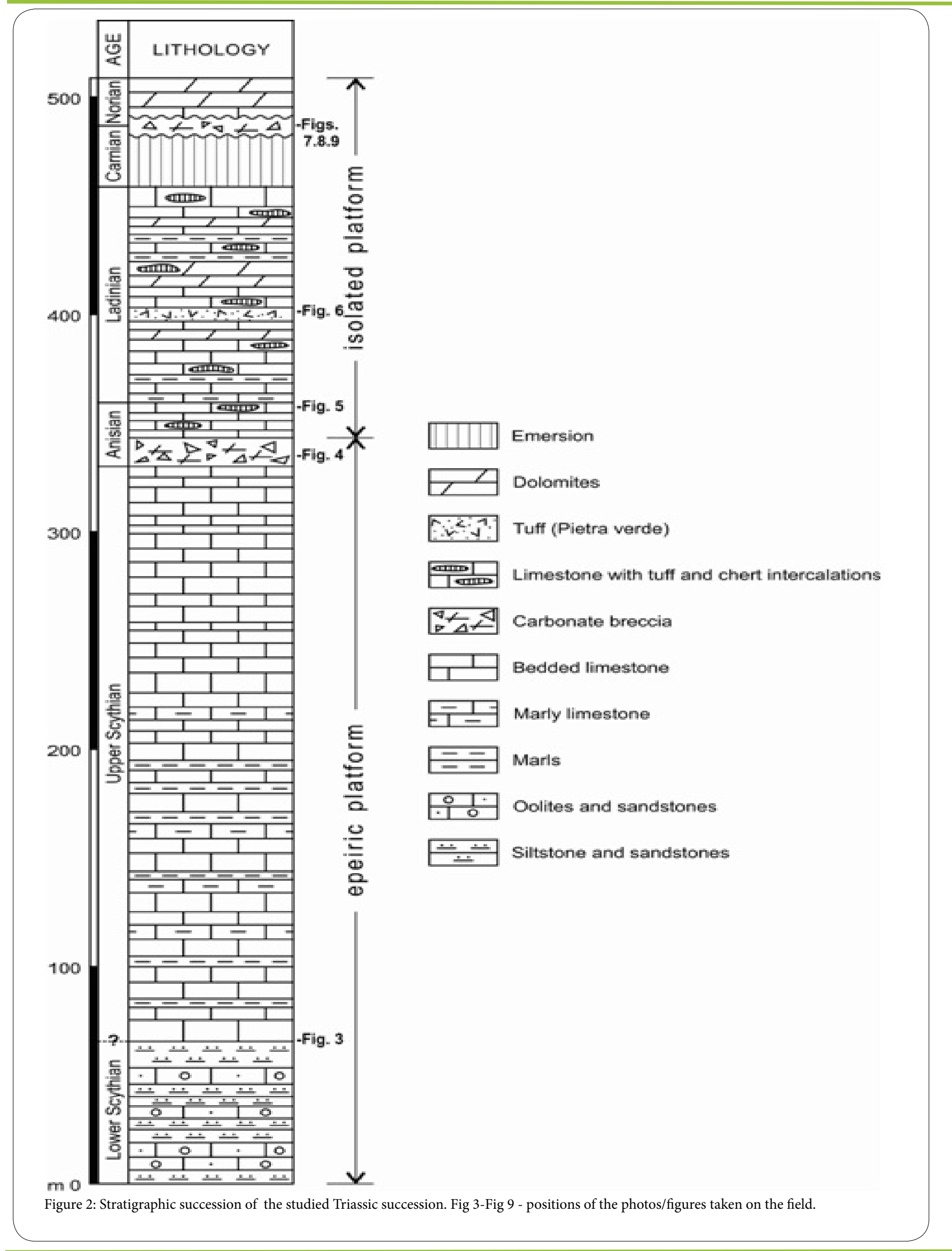


Citation: Bucković D, Štampar A (2016) Triassic Succession of Zelovo Area (Svilaja Mt. - Karst Dinarides, Croatia): A Sedimentary Record from the Epeiric to Isolated Carbonate Platform Transition. Int J Earth Envrion Sci 1: 109. doi: http://dx.doi.org/10.15344/ijees/2016/109
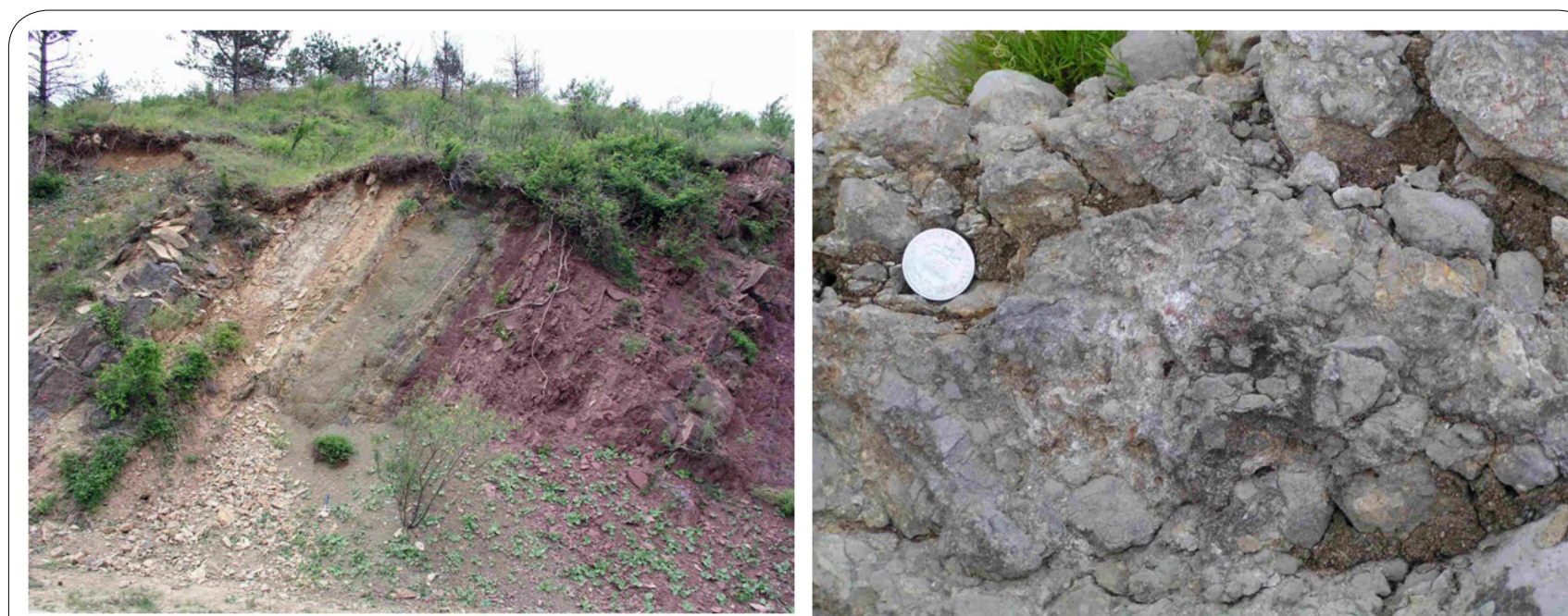

Figure 3: The contact between the Lower Scythian (reddish and violet Figure 4: "Otarnik" carbonate breccias composed of angular and subangular micaceous siltstones-sandstones on the right) and the Upper Scythian limestone and dolomite fragments. The boundary between the Scythian and (greyish marly limestones and marls on the left).

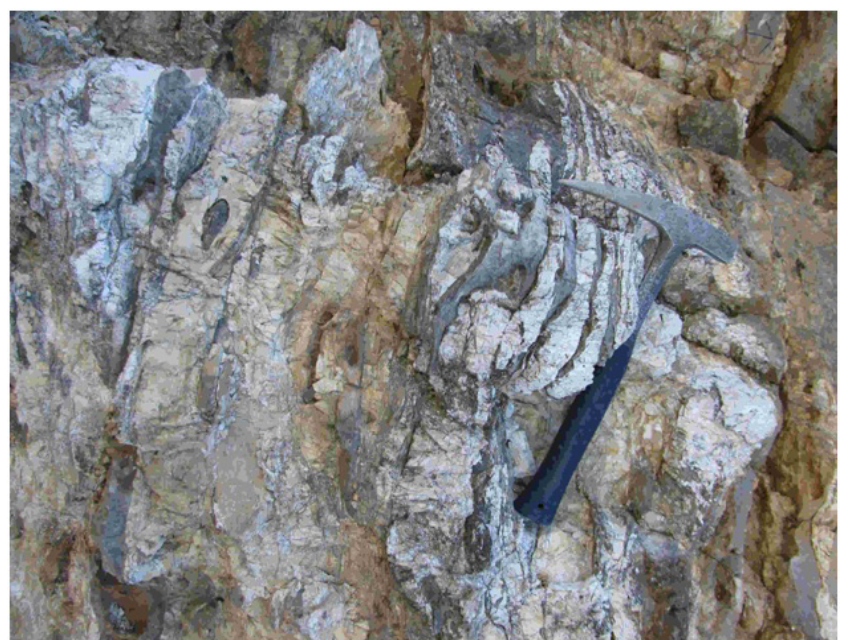

Figure 5: Chert intercalations within the Anisian carbonate beds.

The breccia boundary horizon is $4 \mathrm{~m}$ thick (Figure 7). It is composed of angular and subangular limestone and dolomite fragments that vary in size from a few millimeters to a few centimeters (Figure 8). Larger fragments occur only sporadically. Some fragments contain calcite and/ or dolomite veins. At places, the breccia contains rounded fragments passing thus into a conglomerate. Packing of breccia fragments is dense, while their sorting is poor, without grading or bedding. Predominate type of fragments is white, bioclastic wackestone/ floatstone containing Diplopora annulata Schafhäutl (Figure 9). Other wackestone/floatstone fragments contain rare undeterminable mollusc remains, rounded intraclasts and rare oncoids. Dolomite fragments consist of subhedral to euhedral dolomite crystals with only sporadically preserved original sedimentary structures, such as stromatolitic lamination. The matrix of breccias belongs to finegrained limestone and/or dolomite particles, enriched with reddish bauxitic clayey material. Some larger carbonate particles, incorporated in the matrix, are completely recrystallized. In spots, coarser sparry crystals occur. Sporadic larger cavities are partly matrix-filled or in part spar-filled, revealing geopetal fabrics. the Anisian.

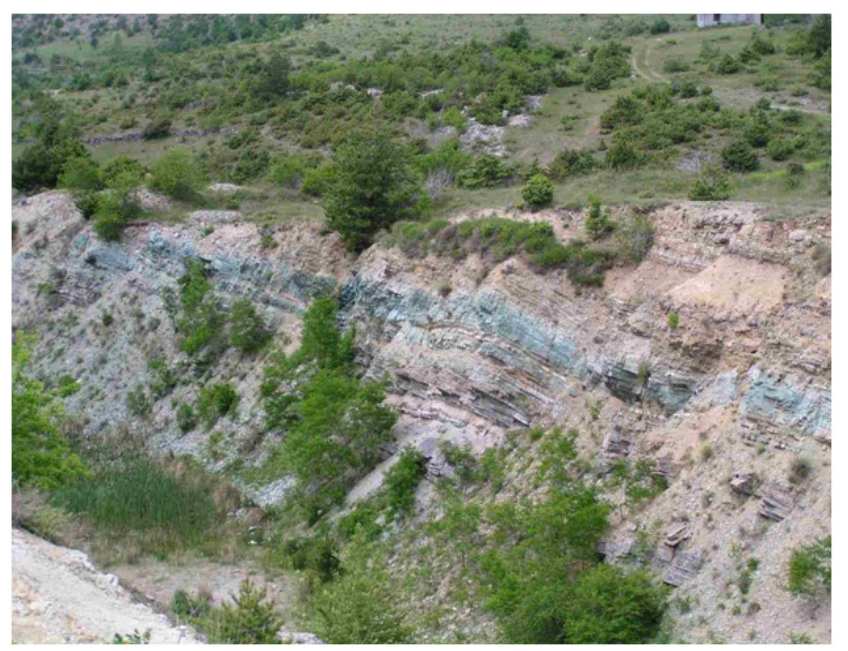

Figure 6: Silicified dolomites and limestones that alternate with green, crystaline and vitric tuffs - "pietra verde" interval within the Ladinain carbonate beds.

The breccia boundary horizon is overlain by an $8 \mathrm{~m}$ thick interval of oolitic packstone/grainstone (Figure 7). This is, in turn, followed by $60 \mathrm{~m}$ thick succession of early- and late-diagenetic dolomites with sporadic planar and corrugated stromatolitic lamination. By their general appearance, the dolomites are similar to the wellknown Alpine Norian-Rhaetian Hauptdolomit. It is thin to medium bedded, moderate grey and/or, in places, yellowish grey in color due to weathering and limonitization of pyrite grains. Early-diagenetic dolomitic varieties, dolomitic limestone as well as dedolomite, respectively, occur sporadically. The late-diagenetic Hauptdolomit beds are monotonous, composed of predominantly subhedral and to a lesser extent euhedral dolomite crystals, so the primary structures are not visible. In places, it shows even a sandy appearance. The earlydiagenetic dolomitic beds show a pretty heterogeneous microfacies composition, with numerous lithological varieties such as dolosparite, dolaointrasparite, dolomicrite, dolopelmicrite and/or stromatolitic dolomite. Sporadically, desiccation and erosion processes broke some of the stromatolitic laminae, forming an intraformational dolomite breccia. Abundant, irregular fenestrae and sporadic undeterminable 
Citation: Bucković D, Štampar A (2016) Triassic Succession of Zelovo Area (Svilaja Mt. - Karst Dinarides, Croatia): A Sedimentary Record from the Epeiric to Isolated Carbonate Platform Transition. Int J Earth Envrion Sci 1: 109. doi: http://dx.doi.org/10.15344/ijees/2016/109

Page 5 of 7

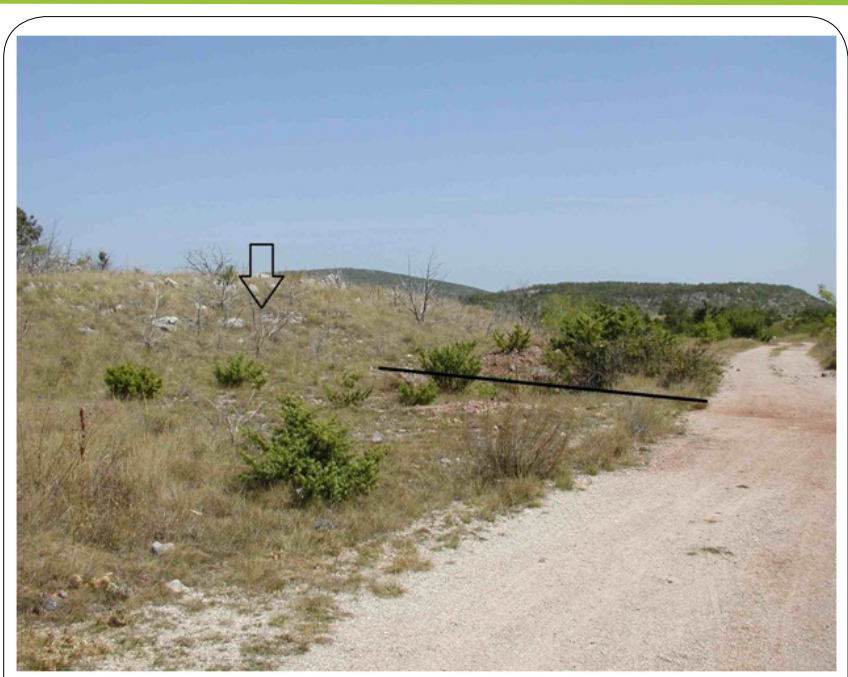

Figure 7: Black line marks the breccia boundary horizon between the Ladinian and Norian-Rhaetian. Arrow points at the beginning of the Norian-Rhaetian carbonate beds (oolitic packstone/grainstone).

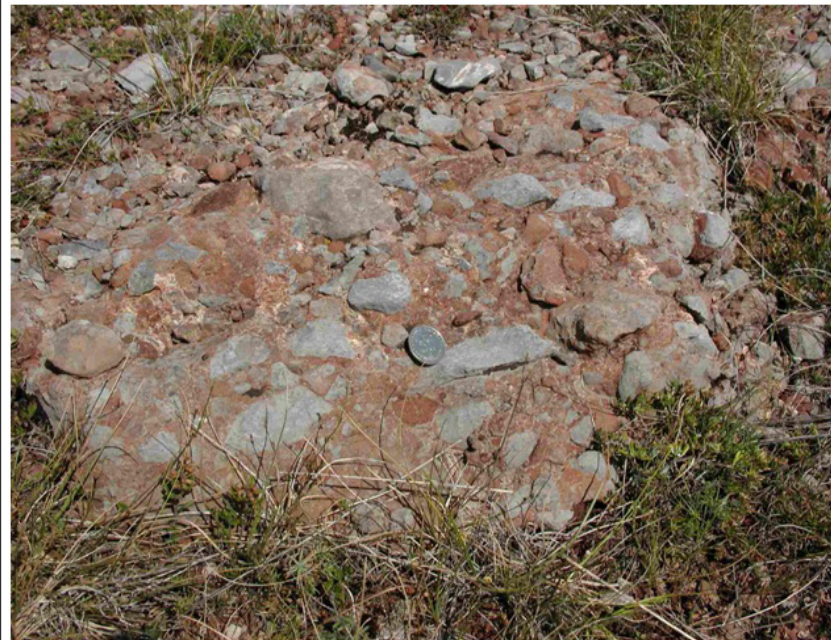

Figure 8: The breccia from the boundary horizon composed of the angular and subangular Upper Ladinian carbonate fragments.

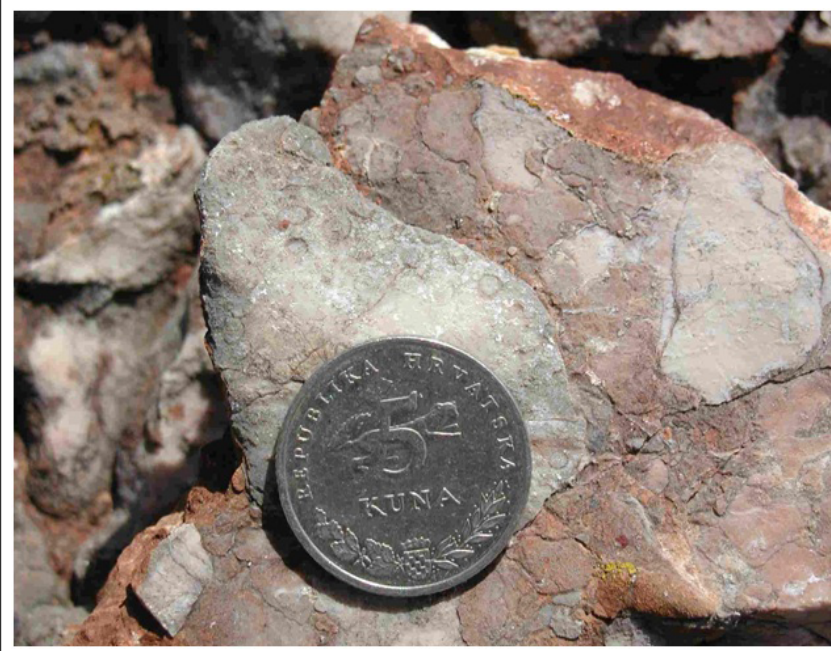

Figure 9: The breccia carbonate fragment from the boundary horizon Small "circles" above the coin represent transverse sections of Diplopora annulata Schafhäutl. algal fragments, moluscs and ostracodes also occur. The irregular fenestrae frequently show geopetal characteristics with lower part filled by vadose crystallic silt, while the rest of the fenestrae is filled with crystallized drusy dolomite cement.

\section{Discussion}

Lower Triassic succession part of Zelovo area reveals common facies features that can be observed in many other Croatian Lower Triassic terrains. Thus it can be assumed that during Early Triassic age, at the southern Tethys area, very similar environmental conditions prevailed on a broad scale. It can be best described as an epeiric ramp environment as proposed by [4] with very low bathymetric slope, a width of many hundreds of kilometers and depositional processes dominated by storms (Figure 10a). This assumption of wide epeiric ramp, i.e. spaceous shallow-marine Gondwana shelf, is supplemented by the earlier hypothesis of continuous sedimentation of Permian and Triassic deposits in tectonically inactive phases on the edges of an epeiric sea $[5,6]$. Presented Lower Triassic facies types at Zelovo area together with the abundance of various textures, clearly indicate shallow-water environment where the wave and storm component or multiple episodes of storm reworking were active. As it was observed and concluded in neighbouring Croatian area by [7], the influence of storms in Lower Triassic beds has been manifested differently depending of water depth, so it can be assumed that also at the Zelovo area this depth related concept of storm generated layers acted in the same way and had its general consequence in forming various structural characteristics among the Lower Scythian and Upper Scythian beds. Therefore, very obvious difference between these beds, which is reflected in different lithology and textural characteristics, imply the changing in water depth in favour of deepening of the epeiric sea environment as a consequence of the transgressive trend [8] (Figure 10b). More detailed explanation of origin of each facies and texture observed within the Lower Triassic beds of Zelovo area is out of scope of this paper.

The boundary between the Scythian and Anisian beds is marked by a local disconformity with intraformational carbonate breccias ("Otarnik" unit). The lateral transition from carbonate breccias to Anisian carbonates clearly indicates that only local, small tectonic uplift led here to emersion and carstfication of the exposed carbonate material at the beginning of Anisian. Thus, the origin of these "Otarnik" breccias is connected with later reworking and redeposition of carstified carbonate material during transgression and then further deepening on the epeiric sea area.

The Anisian epeiric sea deepening event was a result of intense tectonic activity, i.e. rift tectonics [2] that took place throughout the Gondwana shelf, culminating by regional Middle Triassic volcanism $[9,10]$. This led to the separation of one huge shallowmarine Gondwana shelf fragment when one huge isolated carbonate platform came into being within the southern Tethyan realm Adria plate, i.e. Southern Tethyan Megaplatform [1] (Figure 10c). Hereafter siliciclastic input from Gondwana land was disabled and pure carbonate deposition commenced. Numerous tuff intercalations within the Anisian and even Ladinian beds clearly indicate the volcanism events when clouds of ash were being moved by the wind repeatedly and in abundance from a string of active volcanoes situated nearby the rift zone (Figure 10c and d). However, no remnant features of these volcanoes have been identified in the vicinity of Zelovo area. It is probable that volcanic ash falling into deepened Anisian/Ladinian marine environment stimulates "blooms" of various silica-bearing 
Citation: Bucković D, Štampar A (2016) Triassic Succession of Zelovo Area (Svilaja Mt. - Karst Dinarides, Croatia): A Sedimentary Record from the Epeiric to Isolated Carbonate Platform Transition. Int J Earth Envrion Sci 1: 109. doi: http://dx.doi.org/10.15344/ijees/2016/109

Page 6 of 7
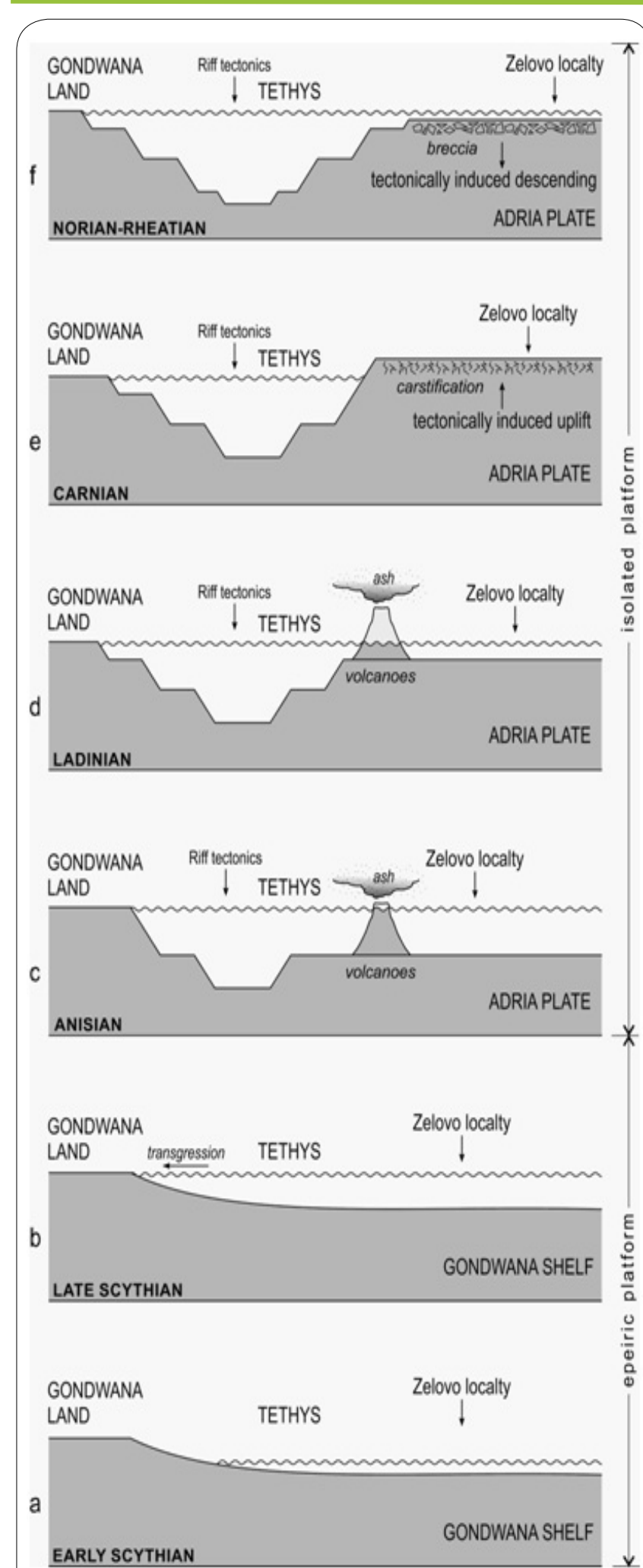

Figure 10: Simplified sketch showing the main paleogeographic events on the northern Gondwana margin; a-b -during Early Triassic epeiric platform phase; c-f - during Middle/Late Triassic rifting processes phase when isolated platform (Adria plate) was formed and then began to move northward (not to scale). organisms such as radiolarians. As these organisms sink, portions of their shells dissolve near the bottom and reprecipitate in void spaces between shell fragments, resulting in hard bedded chert intercalations. Mixed sediments, such as silicified dolomites and limestones are also a result of diagenetic redistribution of these siliceous organisms. Bioclasts such as corals, mollusks, and brahiopods observed in sporadically presented coarse-grained intercalations indicate periodical displacing of coarse-grained detritus from shallow-water environments into the adjacent deepened-water environments. During Early Ladinian high carbonate accumulation rate caused gradual reducing of accommodation space, i.e., decrease of water depth, so typical shallowwater carbonates originated including abundance of Diplopora fragments, oncoids and presence of algal laminations (stromatolitic intraclasts). About the Middle Ladinian the huge portion of Adria plate area was subjected to tectonically induced uplift, superimposed on overall eustatic variations, resulting in regional emersion phase and strong denudation and/or karstification throughout the exposed area [11-17] (Figure 10e). This regional emersion event lasted throughout the whole Carnian. Therefore, within the broader Tethyan realm this event indicated a depositional collapse which resulted in the demise of the existing isolated carbonate deposition [18-21]. Concerning the wider Karst Dinaridic area in Croatia, a disconformity and/or various types of terrestrial depositional intervals were formed during that Late Ladinian/Carnian emersion [22]. At the Zelovo area this regional emersion phase produced notable breccia boundary horizon. As the Ladinian carbonates were subjected to karstification during long-term emersion (Late Ladinian/Carnian), terrestrial phase can be recognized in terms of paleokarst-related solution-collapse breccias as it has been described e.g. by [23]. Thus, it can be assumed that overall Middle Ladinian regression caused dissolution of exposed Ladinian carbonates resulting in an extensive karstification, with solutionenlarged vugs and small caverns beneath the platform surface, producing clast- to matrix-supported chaotic breccias that rested sharply on intact Ladinian beds. Active carbonate dissolution ceased due to subsequent Norian transgression, i.e. Adria plate descending, when sediment loading caused local collapse and fragmentation of karstified surface (Figure 10f). Continued burial led to further fracturing and in situ Norian brecciation, resulting in mosaic and fracture breccia horizon. This Norian transgression event caused the deposition of shallow-water carbonates when thick intertidal NorianRhaetian sequence regionally known as the Hauptdolomit originated. Numerous lithological varieties of early-diagenetic dolomitic beds imply here a peritidal isolated platform environment, where successive shallowing-upward cycles were produced. Nevertheless, late-diagenetic dolomitization destroyed most of the sedimentary and early-diagenetic features, so their occurrences here are pretty sporadic and irregular.

From the beginning of the Hauptdolomit sequence up to the youngest Cretaceous beds in Croatian Karst Dinaridic area, an isolated platform conditions continued to exist on the wide depositional area.

\section{Conclusion}

In the geological evolution of the Zelovo area, attachment to and detachment from the Gondwana landmass is the basic issue. Although the entire carbonate succession of the Karst Dinarides was deposited within carbonate platform environments, there were different types of carbonate platforms located in different palaeogeographical settings in different times. As for the sedimentary signature at the Zelovo area, it is obvious that the pre-Anisian part of succession was undoubtly 
Citation: Bucković D, Štampar A (2016) Triassic Succession of Zelovo Area (Svilaja Mt. - Karst Dinarides, Croatia): A Sedimentary Record from the Epeiric to Isolated Carbonate Platform Transition. Int J Earth Envrion Sci 1: 109. doi: http://dx.doi.org/10.15344/ijees/2016/109

Page 7 of 7

associated with siliciclastic deposits, resembling typical depositional characteristics of the shelf environment, i.e. epeiric carbonate platform situated along the northern Gondwana margin. In contrast, Anisian-Rhaetian part of succession is a product of isolated carbonate platform deposition that started after tectonic activity, culminating by regional Middle Triassic volcanism recorded throughout the Gondwana margin. Then, a huge isolated carbonate Adria plate (Southern Tethyan Megaplatform) was formed. In the initial period of its isolated existence occasional volcanic activity obstructed pure carbonate sedimentation due to volcanic ash input and consequently produced frequent chert intercalations, but starting from the Early Ladinian a typical pure shallow-water carbonates in isolated platform conditions prevailed. Therefore, the Zelovo area is only a local but very affirming indicator of the large-scale paleogeographic events that affected southern Tethyan realm during Triassic age.

\section{Acknowledgement}

The manuscript has highly benefited from the review of Dr Mohamed Khalifa, University of Zawia, Libya and also from the review of one anonymous reviewer.

\section{References}

1. Vlahović I, Tišljar J, Velić I, Matičec D (2005) Evolution of the Adriatic Carbonate Platform: Palaeogeography, main events and depositional dynamics. Palaeogeography, palaeoclimatology, palaeoecology 220: 333 360.

2. Jelaska V, Kolar-Jurkovšek T, Jurkovšek B, Gušić I (2003) Triassic beds in the basement of the Adriatic-Dinaric carbonate platform of Mt. Svilaja (Croatia). Geologija 46/2: 225-230.

3. Jelaska V, Benček $Đ$, Matičec D, Belak M, Gušić I (2000) Geological history and structural evolution of the Outer Dinarides. Excursion Guide-Book Second Croatian Geological Congress: 1-12.

4. Lukasik J.J, James N.P, McGowran B, Bone Y (2000) An epeiric ramp: lowenergy, cool-water carbonate facies in a Tertiary inland sea, Murray Basin, South Australia. Sedimentology 47: 851-881.

5. Ivanović A, Šćavničar B, Sakač K, Gušić I (1971) Stratigraphic position and petrographical characteristics of the evaporite and clastic deposits in the environs of Drniš and Vrlika (Dalmatia). Geol vjesnik 24: 11-33.

6. Tišljar J (1992) Origin and depositional environments of the evaporite and carbonate complex (Upper Permian) from the central part of the Dinarides (Southern Croatia and Western Bosnia). Geol Croatica 45: 115-127.

7. Aljinović D (1995) Storm Influenced Shelf Sedimentation - An Example from the Lower Triassic (Scythian) Siliciclastic and Carbonate Succession near Knin (Southern Croatia and Western Bosnia and Herzegovina). Geo Croatica 48: 17-32.

8. Grimani I, Šikić K, Šimunić A (1975) Geology of the Knin sheet. Savezni geološki zavod Beograd, $61 \mathrm{p}$

9. Channell JET, D'Argenio B, Horváth F (1979) Adria, the African promontory, in Mesozoic Mediterranean palaeogeography. Earth-Science Review 15: 213-292.

10. Pamić J, Gušić I, Jelaska V (1998) Geodynamic evolution of the Central Dinarides. Tectonophysics 297: 251-268.

11. Bosellini A (1991) Geology of the Dolomites - An Introduction. Dolomieu Conference on Carbonate Platform and Dolomitization, $43 \mathrm{p}$.

12. De Zanche V, Gianolla P, Mietto P, Siorpaes C.H, Vail P (1993) Triassic sequence stratigraphy in the Dolomites (Italy). Memorie Scienze Geologiche 45: 1-27.

13. Rüffer TH, Zühlke R (1995) Sequence stratigraphy and sea-level changes in the Early to Middle Triassic of the Alps: a global comparison. Coastal Systems and Continental Margins 1: 161-207.
14. D'Argenio B, Mindszenty A (1995) Bauxites and related paleokarst; tectonic and climatic event markers at regional unconformities. Eclogae geologicae Helvetiae 88: 453-499.

15. Gianolla P, De Zanche V, Mietto P (1998) Triassic sequence stratigraphy in the Southern Alps (Northern Italy): definition of sequence and basin evolution. SEPM Special Publication 60: 723-751.

16. Smuc A, Car J (2002) Upper Ladinian to Lower Carnian sedimentary evolution in the Idrija-Cerkno region, Western Slovenia. Facies 46: 181256.

17. Brack P, Rieber $H$, Nicora A, Mundil R (2005) The global boundary stratotype section and point (GSSP) of the Ladinian stage (Middle Triassic) at Bagolino (Southern Alps, Northern Italy) and its implications for the Triassic time scale. Episodes 28: 13-25.

18. Bosellini A (1984) Progradation geometries of carbonate platforms: examples from the Triassic of the Dolomites, Northern Italy. Sedimentology 31: 1-24.

19. Bosellini A (1989) Dynamics of Tethyan carbonate platforms. SEPM Spec Publ 44: 3-13.

20. Doglioni C, Bosellini A, Vail PR (1989) Stratal patterns: a proposal of classification and examples from the Dolomites. Basin Research 2: 83-95.

21. Keim L, Brandner R, Krystyn L, Mette W (2001) Termination of carbonate slope progradation: an example from the Carnian of the Dolomites, Northern Italy. Sedimentary Geology 143: 303-323.

22. Bucković D, Martinuš $M$ (2010) Triassic terrestrial phase recorded in the carbonate platform successsion of the Karst Dinarides (Croatia). Natura Croatica: periodicum Musei historiae naturalis Croatici 19/1: 213-230.

23. Ryu IC, Doh SJ, Choi SG (2002) Carbonate breccias in the LowerMiddle Ordovician Maggol Limestone (Taebacksan Basin, South Korea): Implications for Regional Tectonism. Facies 46: 35-56. 